\title{
PROTEASES AND LIPASES ACTIVITY OF FUNGI ISOLATED FROM LOCAL CHEESE, REPUBLIC OF YEMEN
}

\author{
Abdul Rahman .A.H.Humaid ${ }^{(1)}$, Al-Ghalibi S. M. S. ${ }^{(2)}$ Abdel- Sater M. A. ${ }^{(3)}$, and Salahaddin R. H. ${ }^{(4)}$ \\ ${ }^{(1,2)}$ Biology Department, Faculty of Science, Sana a University, Sana a, Yemen. \\ (3) Botany Department, Faculty of Science, Assiut University, Assiut, Egypt. \\ (4) Microbiology Department, , Faculty of Science, Taiz University, Taiz, Yemen.
}

\begin{abstract}
A 99 fungal isolates represented 25 species related to 7 genera were isolated in the current study. They were screened for their ability to produce lipase and protease enzymes from the 35 positive isolates for protease. There are only 3 isolates could produce the enzyme in moderate activity which related to Aspergillus niger and A. sydowii. The remaining isolates 32 (91.4\% of the positive isolates) have weakly enzyme production and these belonging to A. flavus, A. sydowii, A. tamarii, M. racemosus, P. citrinum and P. oxalicum. The results revealed that from the 99 tested isolates, about 34 isolates (34.34\%) could produce lipase. 9 isolates $(9.1 \%)$ of $P$. citrinum exhibited high activity for lipase production. Whereas, 8 isolates $(8.1 \%)$ belonging to $P$. expansum, $P$. islandicum and $P$. paxilli could produce lipase enzyme in moderate ability. While the isolates of Mucor circinelloides, M. racemosus P. oxalicum and P. roqueforti were weakly producers.
\end{abstract}

\section{INTRODUCTION}

Enzymes are an organic substance produced by living cells. They have the property of causing and regulating specific chemical reactions inside or outside living cells, responsible for supporting almost all of the chemical reactions that maintain living cells (Desnuelle 1972).

Enzymes are present in all curds and even after the bacteria and fungi die. The major enzymes are protease, lipase, phosphatase, xanthine oxidase and lactoperoxidase (Macrae 1983).

The enzymes come from the milk itself and microbes present in the milk. Pasteurization inactivates many enzymes in the raw milk (Godfredson 1990).

Some of our foods may be enzymedeficient, causing imbalances in our organs, acting as a predisposing cause of disease (Fregapane et al. 1991).

A review of the microbial enzymes used in dairy applications; primarily, milk-clotting enzymes or rennets, recombinant fungal and bacterial rennets for cheese manufacture and fungal lactases for the manufacture of some milk products with reduced content of lactose was presented. Other dairy enzymes include proteinases for accelerated cheese ripening for good flavour also textural development to reduce allergic properties of cow milk products for infants as well lipases for the development of lipolytic flavours in specialty cheeses (Neelakantan 1991),(Amaal et al. 2016), (Ozturkoglu et al. 2016) and(Albuquerque et al. 2017).

Proteases are the most important groups of enzymes constituting the second from the 
third of the total industrial enzymes marketed (Gerhart 1990 and Singh et al. 1990) (Suganthi et al. 2013) and (Ozturkoglu et al. 2016).

They play an important role in the production of fermented foods and in the dairy industry for clotting of milk (Singh et al. 1994) (Císarová et al 2012).

Also the flavour of the final milk product is mainly due to the proteolytic activity (LópezDíaz et al. 1996) (Mozzi,2015) and (Xiaoji et al. 2017).

Penicillium chrysogenum, P. citrinum and Aspergillus fumigatus, respectively (Chou et al. 2001),(Amaal et al. 2016 and Albuquerque et al. 2017).

Fusarium culmorum (Pekkarinen et al. 2002) A. niger (Poza et al. 2000, Paoletti et al. 2001) Lipases (triacylglycerol acylhydrolase) are a group of enzymes that catalyze the hydrolysis of triacylglycerols to diacylglycerols, monoacylglycerols, fatty acids and glycerol at the interface between aqueous and the lipid phase (Veeraragavan 1990 and Thomson et al. 1999) (Suganthi et al. 2013).

Some lipases are nonspecific, catalyzing reactions at all positions in triacylglycerols, while the others are regiospecific, catalyzing reactions at specific positions on the lipid molecules (Sonnet and Gazzillo 1991) (Mina et al. 2017).

The later group of enzymes has many industrial applications including the improvement of flavor through removal of lipids for dairy (Imai and Tsujisaka 1984) and (Xiaoji et al. 2017).

Fungal lipases have been studied since 1950s, and have presented comprehensive reviews. These lipases are being exploited due to their low cost of extraction, thermal and $\mathrm{pH}$ stability, substrate specificity, and activity in organic solvents. The chief producers of commercial lipases are Aspergillus niger, Candida cylindracea, Humicola lanuginosa, Mucor miehei, Rhizopus arrhizus, R. delemar, $\mathbf{R}$. japonicus, R. niveus and R. oryzae (Godfredson 1990 and Lawson et al. 1994).

Lipolytic enzymes were isolated from the culture fluid of Geotrichum asteroides by (Kazanina et al. 1981).

Lipase produced by Trichosporon heteromorphum ATCC 20001 was examined in media containing soyabean oil and residues but at present the strain ATCC 20001 has been reidentified as Geotrichum klebahnii (Veeraragavan and Gibbs 1989).

Lipases are placed after proteases and carbohydrases in world enzyme market and share about $5 \%$ of enzyme market (Suganthi et al. 2013).

They occur in plants, animals and microorganisms and are accordingly classified as plant, animal and microbial lipases. Wherever they exist, their function to catalyze hydrolysis of triglycerides to glycerol and fatty acid. Like carbohydrases and proteases, lipases of microbial origin enjoy greater industrial importance as they are more stable (compared to plant and animal lipases) and can be obtained in bulk at low cost. Majority of yeast lipases are extracellular, monomeric glycoproteins with molecular weight ranging between $\sim 33$ to $\sim 65$ kD. More than $50 \%$ reported lipases producing yeast, produce it in the forms of various isozymes. These lipase isozymes are in turn produced by various lipase encoding genes. Among many lipase producing yeasts Candida rugosa is most frequently used yeast as the source of lipase commercially (Vakhlu and Kour 2006) (Yadave et al. 2012) and (Xiaoji et al. 2017). 
There are several reports on the multiple forms of lipases produced by the microorganism especially filamentous fungi (Fukuda et al. 2001) and (Albuquerque et al. 2017).

This multiplicity has been ascribed to post-transcriptional processing, existence of different genes, deglycosylation etc. Among yeasts, Candida albicans, C. antarctica, C. rugosa, Geotrichum asteroids, G. candidum, Trichosporon fermentans, Saccharomycopsis lipolytica, Yarrowia lipolytica (formally Candida paralipolytica) (Pandey et al. 1999) (Marin et al.2019).

\section{MATERIALS AND METHODS}

\section{1- Organisms and Culture Maintenance.}

Ninety-nine fungal isolates recovered from cheese samples were screened for their ability to produce extracellular enzymes in solid media. The following fungal organisms were tested: Alternaria tenuissima ( 1 isolate); Aspergillus candidus (2); A. flavus (4); A. niger (2); A. ochraceus (9); A. petrakii (1); A. sydowii (8); A. tamarii (6); A. terreus (5); Emericella nidulans (2); Geotrichum candidum (1); Humicola fascoatra (1); Mucor circinelloides (10); M. hiemalis (2); M. racemosus (7); Penicillium aurantiogriseum (1); P. chrysogenum (1); P. citrinum (16); P. expansum (5); P. funiculosum (1); P. islandicum (3); P. oxalicum (3); P. paxilli (2); P. roqueforti (3) and P. steckii (3). These fungi were maintained on Czapek's agar and were subcultured every three weeks.

\section{a) Protease activity.}

The fungal proteolytic activity was tested using a casein hydrolysis medium (Paterson and Bridge 1994),(Ozturkoglu et al 2016).

This medium was intended for presumptive protease activity and contains skim milk which gives an opaque final medium. Hydrolysis of the casein, which may also be due to acid production, result in a clear zone around the fungal colony. The composition of the medium (g/l): $\mathrm{KH}_{2} \mathrm{PO}_{4}, 1.0 ; \mathrm{KCl}, 0.5 ; \mathrm{MgSO}_{4}$ $7 \mathrm{H}_{2} \mathrm{O}, 0.2 ; \mathrm{CaCl}_{2} .2 \mathrm{H}_{2} \mathrm{O}, 0.1 ; 15 \%$ skim milk, 25.0 ml; Glucose, 10; Agar, 12; Distilled water to 1 liter). $15 \%$ skim milk was made by dissolving 3.75g skim milk in $25 \mathrm{ml}$ distilled water and dissolved to a creamy texture prior to adding to the medium. The medium was sterilized by autoclaving at $121 \circ \mathrm{C}$ for 30 minutes. Then the cooled medium was poured into 9 cm Petridishes (20 ml/plate).

\section{b) Lipase activity.}

The lipolytic activity was measured using the method of Ullman and Blasins (1974) with some modification. Tween 80 (poly oxy-ethylene sorbitan mono oleate) was added instead of Tween 20. The basal medium was composed of ; peptone, $1 \%$; $\mathrm{MgSO}_{4} \cdot 7 \mathrm{H}_{2} \mathbf{0}, 0.2 \% ; \mathrm{CaCl}_{2} \cdot 2 \mathrm{H}_{2} \mathrm{O}$, $0.02 \%$; Tween 80, $1 \%$ and Agar-agar, $1.5 \%$; pH 6.0. The medium was sterilized by autoclaving at $121 \circ \mathrm{C}$ for 15 minutes. The Tween 80 was autoclaved separately and $1 \mathrm{ml}$ per $100 \mathrm{ml}$ of sterile was added thin cooled basal medium. Duplicate plates and test tubes were inoculated on the surface of agar by single spot inoculum and were incubated at $28 \circ \mathrm{C}$ for 10 days for fungi. The formation of lipolytic enzymes by a colony was seen either as a visible precipitate due to the formation of crystals of calcium salt of the oleic acid liberated by the enzyme or as opaque zone surrounding the colony consisted of calcium salts of free fatty acid and was usually considered indicative of positive lipolytic activity.

\section{RESULT AND DISCUSSION}

Some 99 isolates represented 25 species related to 7 genera commonly isolated in the 
current study were screened for their ability to produce lipase and protease enzymes. Using solid media and measuring the clear zone around the fungal colonies, we observed the activity of the tested isolates.

\section{1- Protease enzymes.}

Table (1) showed that, of 99 isolates tested for protease production about 35 isolates could produce these enzymes. From the positive isolates 3 isolates $(8.6 \%$ of total positive isolates) related to A. niger and A. sydowii could produce enzyme with moderate activity, The remaining isolates $32(91.4 \%$ of the positive isolates) were weakly enzyme producers and these belonged to A. flavus, A. sydowii, A. tamarii, M. racemosus, $P$. citrinum and $P$. oxalicum. These results were agree to a great extent with findings reported by Robertsen (1984), Mohawed et al. (1993), Singh et al. (1994), Abdel-Gawad (1997), Wu and Hang (2000), Benech et al. (2003),Hickey et al. (2007), (Amaal et al. 2016) and (Ozturkoglu et al. 2016).

They tested several species of fungi including the same species and noticed that these fungi have ability to produce acid or alkaline proteases in different degrees. Also, (Moharram and El-Zyat 1989) and (Feijoo-Siota et al. 2014) tested the ability of different fungal isolates to produce proteolytic enzymes. They observed that most isolates were able to produce protease but in varying degrees. It was also observed that not only the species of a single genus differed in the production of this enzyme but also the different isolates within the same species. Omar et al. (1999) ended an extensive study on the protease activity of (96) fungal isolates. They noticed that from 72 positive isolates, 28 isolates were highly proteolytic, 21 moderately degrading milk protein and the remaining isolates were weakly producers.
Ahmed and Abdel-Sater (2003) reported that, among 73 tested isolates for proteolytic activity about $84.9 \%$ of the isolates (62 isolates) could produce protease enzymes with variable degrees. From the positive strains 30 isolates (48.4\%) exhibited highest protease production and these strains related to Aspergillus niger, $\mathrm{A}$. flavus, A. terreus, and A. sydowii. Nineteen positive isolates could produce enzyme with moderate degree including Fusarium oxysporum, A. niger, Cladosporium and Penicillium species and thirteen (21\%) isolates were weakly producers.

\section{2- Lipase enzyme.}

The results revealed that, from the 99 tested isolates, about 34 isolates $(34.34 \%)$ could produce lipase enzymes. 9 isolates $(9.1 \%)$ of $\mathbf{P}$. citrinum exhibited high lipase production. Whereas, 8 isolates (8. \%) 1belonging to $\mathbf{P}$. expansum, P. islandicum, P. oxalicum and $\mathbf{P}$. paxilli could produce lipase enzyme in moderate ability. On the other hand, from the positive isolates $17.2 \%$ (17 isolates) had weakly enzyme production and these including isolates related to Geotrichum candidum, Mucor circinelloides, M. racemosus, $P$. citrinum, $P$. funiculosum, $\mathbf{P}$. islandicum, P. paxilli, p. oxalicum, and $P$. roqueforti (Table 1) Most of the species tested were previously screened for their lipolytic abilities and showed the capability for enzyme synthesis with variable degrees depending on the isolates tested (Moharram et al. 1988, LópezDíaz et al. 1996, Garcia-Lepe et al. 1997, Laila et al. 1998, Boutroua and Gueguenb 2005 and Miroslawa et al. 2006) and Marie et al. 2019).

Our results agree to some extent with the findings reported by López-Díaz et al. (1996) who studied the lipolytic activity of nine isolates of Penicillium roqueforti. They found that all of them capable to produce lipase enzyme. Garcia- 
Lepe et al. (1997) and (Mina et al. 2017) tested 51 fungal isolates for lipase activity and noticed that only $25 \%$ of the isolates were lipase producers. Also, Laila et al. (1998) made an extensive study on lipase production by 90 fungal isolates identified from keratinaceous materials and observed that $38 \%$ of the isolates have the ability to produce this enzyme. Barakat and Abdel-Sater (1999) and Ozturkgh et al. (2016) examined one hundred and five fungal isolates collected from raw butter (Milk products) and noticed that, 69 isolates showed lipolytic activity with variable degrees. Among these isolates, 14 isolates exhibited high activity, 24 with moderate and 31 were weakly producers other wise Penicillium candidum (PCA 1/TT031) synthesizes different types of extracellular proteases. The objective of this study is to optimize polyethylene glycol (PEG)/citrate based on an aqueous two-phase system (ATPS) and Response Surface Methodology (RSM) to purify protease from Penicillium candidum (PCA 1/TT031).The effects of different PEG molecular weights (1500-10,000 g/mol), PEG concentration (9\%$20 \%)$, concentrations of $\mathrm{NaCl}(0 \%-10 \%)$ and the citrate buffer $(8 \%-16 \%)$ on protease were also studied. The best protease purification could be achieved under the conditions of $9.0 \%$ (w/w) PEG 8000, 5.2\% NaCl, and $15.9 \%$ sodium citrate concentration, which resulted in a onesided protease partitioning for the bottom phase with a partition coefficient of 0.2 , a 6.8 -fold protease purification factor, and a yield of $93 \%$ (Alhelli et al. 2016).

Chahinian et al. (2000), Alhelli et al. (2016) reported that, amongest fungi, the genus Penicillium contains many lipase producers. Hiol et al. (2003) could isolate several lipolytic fungi from palm fruits, and they found two extracellular lipases from Mucor hiemalis, f. Hiemalis and Rhizopus oryzae. Wahba (2003) studied 31 isolates representing 7 species for lipase production. He found that, the most active isolates for enzyme production were related to A. niger and A. alternata whereas, moderate activity was achieved by A. tenussima, F. moniliforme, M. racemosus, $P$. aurantiogriseum, P. chrysogenum and $\mathbf{P}$. corylophilum. A. terreus, E. purpurascens and one isolate of $P$. corylophilum showing no activity. Akiba et al. (2004) reported that, the lipases of Penicillium aurantiogriseum have been extensively studied and found industrial application in the production of monoacylglycerides. Two strains of filamentous fungi, classified as Mucorales, from the pure culture collection (Institute of Technical Biochemistry in TU of Lodz) that known to be efficient producers of intracellular lipases, and they observed very high hydrolytic and synthetic activities (approximately 10 and 5 katal/g of membrane-bound lipase (MBL) preparations, respectively).These two strains (M. circinelloides and M. racemosus). When cultured in media optimized for the biosynthesis of lipases, simultaneously accumulate large amounts of lipids in their mycelia (Antczak et al. 1999 and Antczak 2001).

Amounts of lipids, which were extracted from mycelia of these strains (as a by-product of enzyme biosynthesis) with organic solvent (e.g. with acetone when the active MBL preparations were obtained), reached 20 g/l (40 - $60 \%$ biomass d.w.) which implied that they could be used as a source of SCOs. Due to a scarcity of reports on eukaryotic, oleaginous species capable of storing such large amounts of lipids (Ratledge 2002, Somashekar et al. 2002, Papanikolaou et al. 2004 and Kamzolova et al. 2005) and Mina et al. 2017). 
Table (1): Number of tested isolates (NTI) and number of Positive isolates (NPI) screened for lipase and protease production.

\begin{tabular}{|c|c|c|c|c|c|c|c|c|c|}
\hline \multirow{3}{*}{ Species } & \multirow{3}{*}{ NIT } & \multicolumn{4}{|c|}{ Lipase } & \multicolumn{4}{|c|}{ Protease } \\
\hline & & \multirow{2}{*}{ NIP } & \multicolumn{3}{|c|}{ Degree of production } & \multirow{2}{*}{ NIP } & \multicolumn{3}{|c|}{ Degree of production } \\
\hline & & & $\mathbf{H}$ & $\mathbf{M}$ & $\mathbf{W}$ & & $\mathbf{H}$ & $\mathbf{M}$ & $\mathbf{W}$ \\
\hline Alternaria tenuissima & 1 & $\mathbf{0}$ & - & - & - & - & - & - & - \\
\hline Aspergillus candidus & 2 & $\mathbf{0}$ & - & - & - & 1 & - & - & 1 \\
\hline A. flavus & 4 & $\mathbf{0}$ & - & - & - & 3 & - & - & 3 \\
\hline A. niger & 2 & $\mathbf{0}$ & - & - & - & 2 & - & 2 & - \\
\hline A. ochraceus & 9 & $\mathbf{0}$ & - & - & - & 1 & - & - & 1 \\
\hline A. petrakii & 1 & $\mathbf{0}$ & - & - & - & 1 & - & - & 1 \\
\hline A. sydowii & 8 & $\mathbf{0}$ & - & - & - & 6 & - & 1 & 5 \\
\hline A. tamarii & 6 & $\mathbf{0}$ & - & - & - & 2 & - & - & 2 \\
\hline A. terreus & 5 & $\mathbf{0}$ & - & - & - & 1 & - & - & 1 \\
\hline Emericella nidulans & 2 & $\mathbf{0}$ & - & - & - & - & - & - & - \\
\hline Geotrichum candidum & 1 & 1 & - & - & 1 & 1 & - & - & 1 \\
\hline Humicola fascoatra & 1 & $\mathbf{0}$ & - & - & - & 1 & - & - & 1 \\
\hline Mucor circinelloides & 10 & 4 & - & - & 4 & - & - & - & - \\
\hline M. hiemalis & 2 & $\mathbf{0}$ & - & - & - & - & - & - & - \\
\hline M. racemosus & 7 & 2 & - & - & 2 & 2 & - & - & 2 \\
\hline Penicillium aurantiogriseum & 1 & $\mathbf{0}$ & - & - & - & - & - & - & - \\
\hline P. chrysogenum & 1 & $\mathbf{0}$ & - & - & - & - & - & - & - \\
\hline
\end{tabular}

$W=$ Weak $\leq 0.5 \mathrm{~cm} \quad M=$ Moderate $0.5 \mathrm{~cm} \quad H=H i g h \geq 1 \mathrm{~cm}$ Table (1): Continued

\begin{tabular}{|c|c|c|c|c|c|c|c|c|c|}
\hline \multirow{3}{*}{ Species } & \multirow{3}{*}{ NTI } & \multicolumn{4}{|c|}{ Lipase } & \multicolumn{4}{|c|}{ Protease } \\
\hline & & \multirow{2}{*}{ NIP } & \multicolumn{3}{|c|}{ Degree of production } & \multirow{2}{*}{ NPI } & \multicolumn{3}{|c|}{ Degree of production } \\
\hline & & & $\mathbf{H}$ & $\mathbf{M}$ & $\mathbf{W}$ & & $\mathbf{H}$ & $\mathbf{M}$ & $\mathbf{W}$ \\
\hline P. chrysogenum & 1 & 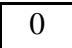 & 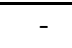 & - & 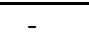 & - & - & - & - \\
\hline P. citrinum & 16 & 13 & 9 & 1 & 3 & 13 & - & - & 13 \\
\hline P. expansum & 5 & 3 & - & 3 & - & - & - & - & - \\
\hline P. funiculosum & 1 & 1 & - & & 1 & - & - & - & - \\
\hline P. islandicum & 3 & 3 & - & 2 & 1 & - & - & - & - \\
\hline P. oxalicum & 3 & 3 & - & 1 & 2 & 1 & - & - & 1 \\
\hline$P$. paxilli & 2 & 2 & - & 1 & 1 & - & - & - & - \\
\hline P. roqueforti & 3 & 2 & - & - & 2 & - & - & - & - \\
\hline P. steckii & 3 & 0 & - & - & - & - & - & - & - \\
\hline Total isolates & 99 & 34 & 9 & 8 & 17 & 35 & $\mathbf{0}$ & 3 & 32 \\
\hline
\end{tabular}

$W=$ Weak $\leq 0.5 \mathrm{~cm} \quad M=$ Moderate $0.5 \mathrm{~cm} \quad H=H i g h \geq 1 \mathrm{~cm}$ 


\section{REFERENCES}

Abdel-Gawad K. M. (1997): Microbial and some physiological studies of keratinophilic and other moulds associated with sheep wool. Microbiol. Res. 152: 181 - 188.

Ahmed K. E. and Abdel-Sater M. A. (2003): Mycological quality of Laban Rayeb sold in Assiut City. Assiut Vet. Med. J. 49 (99):75 -77

Akiba T., Yamaguchi S., Suzuki S., Isobe K. and Matsunaga K. (2004): Lipase, its production and use for assay of triglycerides, US Patent 4999289.

Alhelli A.M., Abdul Manap M.Y., Mohammed A.S., Mirhosseini H., Suliman E., Shad Z., Mohammed NK., and Meor Hussin AS (2016): Response Surface Methodology Modelling of an Aqueous Two-Phase System for Purification of Protease from Penicillium candidum (PCA 1/TT031) under Solid State Fermentation and Its Biochemical Characterization. Int J Mol Sci. 11;17(11).

Antczak T., Hiler D., Krystynowicz A., Szczesna M., Bielecki S. and Galas E. (1999): Activity of immobilized in situ intracellular lipase from Mucor circinelloides and Mucor racemosus in synthesis of sucrose esters. Progress in biotech. 17 : 221 - 228.

Antczak T. (2001): Mucor circinelloides and Mucor racemosus: otrzymywanie katalityczne wła'sciwo'sci. Habilitation. Poland: Tech. Univ. Lodz, Inst. Tech. Biochem.

Barakat A. and Abdel-Sater M. A. (1999): Preliminary characterization and lipolytic activity of moulds associated with raw butter. Bull. Fac. Sci. Assiut Univ.28(1):112-116.

Benech R. O., Kheadr Lacroix E. E. C. and Fliss I. (2003): Impact of nisin producing culture and liposome-encapsulated nisin on ripening of Lactobacillus added-Cheddar cheese. J. Dairy Sci. 86: 1895 - 1909.
Boutroua R. and Gueguenb M. (2005): Interests in Geotrichum candidum for cheese technology. Int. J. Food Microbiol. 102: 1 - 20.

Chahinian H., Vanot G., Ibrick A., Rugani N., Sarda L. and Comeau L. C. (2000): Production of extracellular lipases by Penicillium cyclopium purification and characterization of a partial acylglycerol lipase, Biosci. Biotech. Biochem. 64 : 215 - 222.

Chou H., Lai H. Y., Tam M. F., Chou M. Y., Wang S. R., Hon S. H. (2001): cDNA cloning, biological and immunological characterization of the alkaline serine protease major allergen from Penicillium chrysogenum. Int. Arch. Allergy Immunol.127: 15 - 26.

Desnuelle P. (1972): In the Enzymes III (ed. Boyer, P. D.), Academic Press, New York, P. 575 - 616.

Fregapane G., Sarney D. B. and Vulfson E. N. (1991): Enzyme Microbiol. Tech. 13: 796 - 800.

Fukuda H., Kondo A., and Noda H. (2001): Biodiesel fuel production by transesterification of oils. J. Biosci. Bioeng. 92: 405 - 416.

Garcia-Lepe R., Nucro O. M., Reyes F. and Santamaria (1997): Lipase in autotyped cultures of filamentous fungi. Letter Appl. Microbiol. 25: 127 - 130.

Gerhart Z. W. (1990): Enzymes in industry. Production and Applications. p.88. Weinheim: VCH.

Godfredson S. E. (1990): In Microbial Enzymes and Biotechnology (eds Fogarty, W. M. and Kelly, E. T.), Elsev. Appl. Sci. The Netherlands, P. 255 - 273.

Hickey D. K., Kilcawley K. N., Beresford T. P., and Wilkinson M. G. (2007): Lipolysis in Cheddar cheese made from Raw, 
Thermized, and Pasteurized Milks. J. Dairy Sci. 90:47-56.

Hiol A., Jonzo M. D., Druet D. and Comeau L. C. (2003): Production, purification and characterization of an extracellular lipase from Mucor hiemalis f. hiemalis. Ent. Microbiol. Techol. 25: 80 - 87.

Imai M. and Tsujisaka Y. (1984): Fungal lipase, in: Borgstrom, B., Brockman, H.L. (Eds.), Lipases. Elsev. Sci. Publ. P : 443 469.

Kamzolova S. V., Morgunov I. G., Aurich A., Perevoznikova O. A., Shishkanova N. V. and Stottmeister U. (2005): Lipase secretion and citric acid production in Yarrowia lipolytica yeast grown on animal and vegetable fat. Food Tech. Biotech. 43: 113 - 22.

Laila A. Nasser, EL-Shanawany A. A. and Barakat A. (1998): Ecological and physiological studies on fungi associated with camel hairs from Saudi Arabia. 8th Con. 15 - 17. No. 1998, Fac. Vet. Med. Assiut Univ. Egypt.

Lawson D. M., Brzozowski A. M., Dodson G. G., Hubbard R. E., Huge-Jensen B., Boel, E. and Derewenda Z. S. (1994): In Lipases: their Structure, Biochemistry and Application (eds Woolley, P. and Petersen, S. B.), Cambridge Univ. Press, UK, P. 77 - 94.

López-Díaz T. M., Román-Blanco C., García-Arias M. T., García-Fernández M. C. and García-López M. L. (1996): Mycotoxins in two Spanish cheese varieties. Int. J. Food Microbiol. 30 (3): 391 - 395.

Macrae A. R. (1983): In Microbial Enzymes and Technology (ed. Fogarty, W. M.), Appl. Sci. London, P. 225 - 250.

Miroslawa S-A., Tadeusz A., Malgdalena P-W., Magorzata R., Nina B., Stanisaw B. (2006): Relationships between lipases and lipids in mycelia of two Mucor strains. Enzyme and Microbiol.Tech . 39: 1214 1222.

Moharram A. M., Abdel-Gawad K. M. and EL Maraghy S. S. M. (1988): Ecological. and physiological studies on fungi associated with human hair. Folia Microbiol. 33: 363 - 371.

Moharram A. and El-Zayat S. A. (1989): Lipase and Protease production by fungi isolated from scales of Tilapia nilotica. Bull. Fac. Sci. Assiut Univ. 18 (I-D): 109 - 117.

Mohawed S. M, El-Sharony H. M. and Badran R. A. M. (1993): Studies on the protease activity of some fungi isolated from Tilapia fish in river Nile water. Bull. Fac. Sci. Qena (Egypt) 1 (2): 147 - 171.

Neelakantan S., Mohanty A. K. and Jai K. K. (1991): Production and use of microbial enzymes for dairy processing. Dairy Microbiol. Division, Nat. Dairy Res. Inst. Karnal 132 001, India.

Omar S. A., Barakat A. and EIShanawany A. A. (1999): Microbial degradation of chicken feather by saprophytic fungi. Bull. Fac. Sci. Assiut Univ. 28 (I-D): 123 - 138.

Pandey A, Benjamin S., Soccol C. R., Nigam P, Krieger N. and Soccol V. T. (1999): The realm of microbial lipases in biotechnology. Biotech. Appl. Biochem. 29 (2): 119-131.

Paoletti M., Castroviejo M., Begueret J. and Clave C. (2001): Identification and characterization of a gene encoding a subtilisinlike serine protease induced during the vegetative incompatibility reaction in Podospora anserine. Curr. Gene. 39: 244 - 252.

Papanikolaou S., Komaitis M., Aggelis G. (2004): Single cell oil (SCO) production by Mortierella isabellina grown on high-sugar content media. Bioresour Tech. 95: 287 - 291.

Paterson R. R. M. and Bridge P. D. (1994): Biochemical techniques for filamentous 
fungi. Int. Mycol. Inst. CAB Int. Surrey, P. 21, UK.

Pekkarinen A. I., Jones B. L, NikuPaavola M. L. (2002): Purification and properties of an alkaline protease of Fusarium culmorum. Eur. J. Biochem. 269: 798 - 807.

Poza M., ke Miyuel T., Sievro C. and Villa T. G. (2000): Characterization of a broad pH range protease of Candida caseinolytica. $\mathrm{J}$. Appl. Microbiol. 91: 916 - 921.

Raper K. and Thom C. (1949): A manual of the Penicillium. Williams and Wilkins, Baltimore, USA.

Raper K. B. and Fennell D. 1. (1965): The genus Aspergillus. Williams and Kilkins, Baltimore, USA.

Ratledge C. (2002): Regulation of lipid accumulation in oleaginous microorganisms. Biochem. Soc. Trans. 30: 1047 - 1050.

Robertsen B. (1984): An alkaline extra cellular protease produced by Cladosporium cucumerinum and its possible importance if $\mathrm{L}$ : .C development of scab disease of cucumber seedlings. Phys. Plant. Patho. 24: 83 - 92.

Singh A., Kuhad R. C. and Saxena R. K. (1990): Microbial enzymes and food industry. Microbiol. Today 1: 19 - 27.

Singh A., Ghosh K. and Ghosh P. (1994): Production of thennostable acid protease by Aspergillus niger. Lett. Appl. Microbiol. 18: 177 - 180.

Somashekar D., Venkateshwaran G., Sambaiah K. and Lokesh B. R. (2002): Effect of culture condition on lipid and gamma-linoleic acid production by mucorales fungi. Proc. Biochem. 38: 1719 - 1724.

Sonnet P. E. and Gazzillo J. A. (1991): Evaluation of lipase selectivity of hydrolysis. J. Amer. Oil Chem. Soc. 68: 11 - 15.
Thomson C. A., Delaquis P. J. and Mazza G. (1999): Detection and measurement of microbial lipase activity: Rev. Crit. Rev. in Food Sci. and Nutrition 39: 165 - 187.

Uliman V. and Blasins G. (1974): A simple medium for the detection of different lipolytic activity of micro-organisms. Zentrabi. Bakteriol. Hyg. II Abt. A. J. Food Prot. (69): 264 - 267.

Vakhlu J. and Avneet K. (2006): Yeast lipases: enzyme purification, biochemical properties and gene cloning, Dep. Biotech, Univ. Jammu, Jammu-180006 (J and K) India.

Veeraragavan $K$. and Gibbs B. F. (1989): Detection and partial purification of two lipases from Candida rugosa. Biotech. Letters. 11 : 345 - 348.

Veeraragavan K. (1990): A simple and sensitive method for the estimation of microbial lipase activity. Anal. Biochem. 186: 301 - 305.

Xiaoji Z., Kaixiong L., Xuewei S., Yongqing N., Baokun L. and Bin Z.(2017): Potential characterization of yeasts isolated from Kazak artisanal cheese to produce flavoring compounds.Wiley Microbiology Open.(3):533.

Wahb Nahed M. M (2003): Assessment of the mycological status of butter sold in Assuit Governorate. The second int. congress of food hygiene and human health. Animal Health Inst. Assuit Branch. Dep. of Food Hygiene. Fac. Vet. Med. Assiut-Egypt.

William J. H. (1973): Standard methods for the examination of dairy products, 13 th. Edi. P. 315 - 317. A. P. H. A. (Kohman Method 1973)

Wu L. C. and Hang Y. D. (2000): Acid protease production from Neosartorya fischeri. J. Dairy Sci. 33 (1): 44 - 47. 
Suganthi, C.; Mageswari, A.; Karthikeyan, S.; Anbalagan, M.; Sivakumar, A.; Gothandam, K. (2013): Screening and optimization of protease production from a halotolerant Bacillus licheniformis isolated from saltern sediments.J. Genet. Eng. Biotechnol., 11, 47-52.

Císarová, M.; Tancinová, D.; Barboráková, Z.; Masková, Z.; Felsöciová, S.; Kucerková, V. (2012): Potential production of cyclopiazonic acid by penicillium camemberti strains isolated from camembert type cheese. $\mathrm{J}$. Microb. Biotechnol. Food Sci. 2, 434-435.

Amaal M. A., Mohd Y. A. ,Abdulkarim S. Mohammed H. M., Eilaf S. ,Zahra S., Nameer K. M. and Anis Sh. M.H.(2016):Response Surface Methodology Modelling of an Aqueous Two-Phase System for Purification of Protease from Penicillium candidum (PCA 1/TT031) under Solid State Fermentation and Its Biochemical Characterization Int. J. Mol. Sci. 17, 1872.

Yadav, J. S. S., Bezawada, J., Yan, S., Tyagi, R. D., \& Surampalli, R. Y: (2012).

Candida krusei: Biotechnological potentials and concerns about its

safety. Canadian Journal of

Microbiology, 58, 937-952.
Ozturkoglu B. S., Wiebenga A.M., Bron P.A.,Vries R.P.(2016): Protease and lipase activities of fungal and bacterial strains derived from an artisanal raw ewe's milk cheese. Int J Food Microbiol. 21;237:17-27.

Feijoo-Siota L, Blasco L, RodríguezRama JL, Barros-Velázquez J, Miguel Td, Sánchez-Pérez A and Villa TG1.(2014): Recent patents on microbial proteases for the dairy industry.

Recent Adv DNA Gene Seq. 8(1):44-55.

Morrissey, J. P., Etschmann, M. M., Schrader, J., \& de Billerbeck, G. M. (2015): Cell factory applications of the yeast Kluyveromyces marxianus for the biotechnological production of natural flavour and fragrance molecules. Yeast, 32, 3-16.

Marie Vandermies and Patrick Fickers (2019):Bioreactor-Scale Strategies for the Production of Recombinant Protein in the Yeast Yarrowia lipolytica. Microorganisms.7: 40.

Mina Z., Gholamhossein E. and Hossein S. (2017): Lipase and biosurfactant from Ochrobactrum intermedium strain MZV101isolated by washing powder for detergent

application Lipids in Health and Disease 16:177 


\section{نشاط إنزيمات البروتين والد هون للفطريات المعزولة من الجبنه المحلية - الجمهوريّة البمنية \\ عبدالرحمن عبدالله حميد(')- سعيد منصر الغالبي (')- رياض صلاح الدين(")- محمد عبدالستار (")

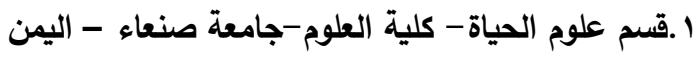 \\ r.قسم الميكروبيولوجي- كلية العلوم التطبيقية-جامعة تعز - اليمن r.قسم النبات - كلية العلوم - جامعة أسيوط- مصر}

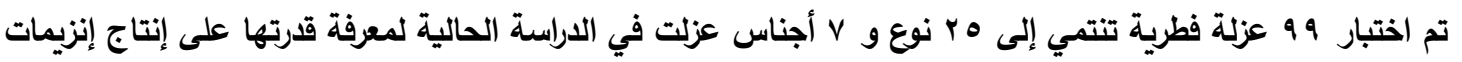

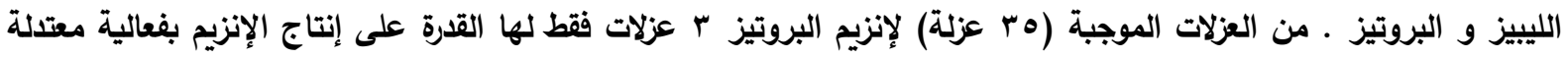

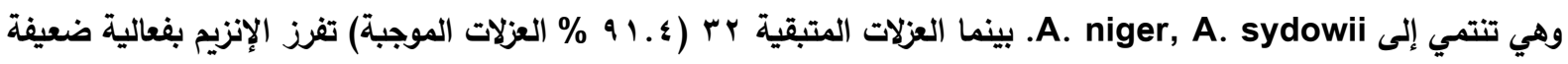
وهي تتمثل بـ

A. flavus, A. sydowii, A. tamarii, M. racemosus, P. citrinum, P. oxalicum.

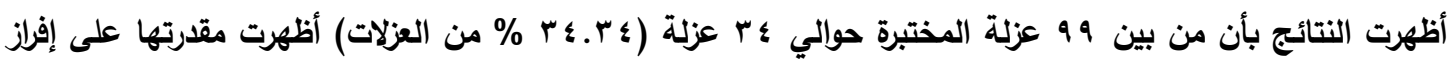

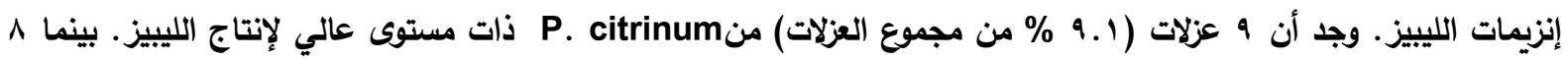

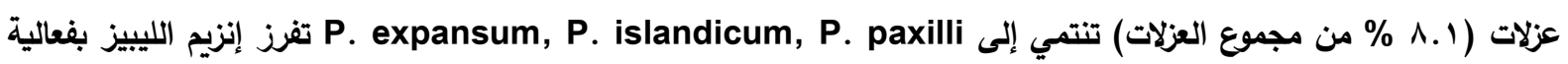

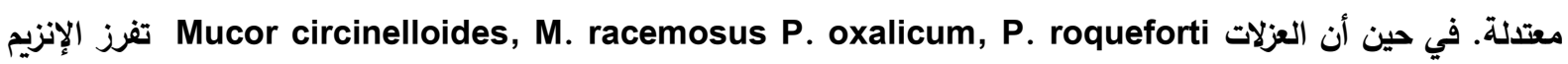

بفعالية ضعيفة. Extraction protease expressed by Penicillium fellutanum from the Brazilian savanna using poly(ethylene glycol)/sodium polyacrylate/ $\mathrm{NaCl}$ aqueous two- phase system. 